MATEC Web of Conferences 6, 01001 (2013)

DOI: $10.1051 /$ matecconf/20130601001

(C) Oivned by the authors, published by EDP Sciences, 2013

\title{
Fire spalling of concrete - A historical overview
}

\author{
R. Jansson \\ SP Technical Research Institute of Sweden
}

\begin{abstract}
This paper presents a historical overview of fire spalling of concrete between the mid-1800s through to modern time. Several of the observations presented are put into a modern context by additional discussion.
\end{abstract}

\section{INTRODUCTION}

These days a great deal of focus is put on the fire spalling in high strength concrete but the occurrence of spalling during fire exposure of concrete has always been a more or less common phenomenon. As all the physics involved in the phenomenon are not yet understood it is of interest to look back and see what observations and theories have previously been put forward regarding this subject. It is important to remember when reading about the different observations and theories presented that the material "concrete" has been changed dramatically during the past 150 years. Despite this it is the author's humble hope that this short compilation will broaden our perspective and inspire us all to think outside of the box. Indeed, I believe that only by understanding historical data in the modern context of new information and theories can we hope to develop a deeper understanding of this highly complex phenomenon. Now join me as we embark on a fast journey across the fire spalling of concrete from 1854 to the present.

\section{HISTORICAL TIMELINE}

1854 First recorded observation of fire spalling of concrete. Probably the first description of the spalling behavior of concrete during fire was made in a publication by Barret [1]. He described a discussion where Mr. Tite stated that if flint was used as an aggregate in concrete it would "split, and yield under the action of fire".

1866 Recognition that rapid cooling of heated concrete building elements could precipitate spalling. According to Ingle [2], some of the numerous instances of destruction by fire of concrete buildings, which were supposed to be fire resistant, are probably due to the application of water during fire fighting. This is probably a rare scenario but there is at least one documented example of this. During a fire event, described by the Swedish Tariff Association [3], pre-stressed beams were used as targets for distributing water in the fire enclosure with the consequence that a large part of the webs of the beams spalled away. In contrast with this experience it was surmised by Kordina [4] during a workshop in Braunschweig on the subject of fire resistance of pre-stressed concrete that the hose steam test did not appear to result in dangerous spalling.

1905 Observations of liquid water coming out of the unexposed side of concrete during fire testing. Woolson [5] first recorded the flow of liquid water from the cold side of a concrete sample during fire tests on floor slabs. This is a very common phenomenon during fire testing of concrete. After

This is an Open Access article distributed under the terms of the Creative Commons Attribution License 2.0, which permits unrestricted use, distribution, and reproduction in any medium, provided the original work is properly cited. 


\section{MATEC Web of Conferences}

as little as 40 minutes of single-sided fire exposure to a $30 \mathrm{~cm}$ thick concrete slab, water can pour out from the cold surface of the specimen. This illustrates the fact that during fire exposure a continuous crack system is present through the cross-section of the specimen. This crack system is probably a mixture of cracks already present before the fire test and new cracks developed during the fire exposure. Experience from fire testing shows that only a couple of minutes after the start of fire exposure from below, a curvature can be measured on the top of $250 \mathrm{~mm}$ thick reinforced slabs [6]. Modeling the flow of water in the cold area of a fire exposed concrete sample in the continuous crack system is one of the major challenges that needs to be overcome if a detailed thermo-hydro-mechanical model of fire spalling is to be successful.

1905 Recognition of the significance of age prior to fire testing for the fire spalling behavior of concrete samples. Miller discovered [7] that if fire testing of concrete is performed too soon after manufacture, huge quantities of water must be driven off leading to disintegration due to the expulsion of the water from the specimen and its conversion into steam. Out of fourteen tests performed on loaded slabs only eight were "successful". Even in successful tests, the concrete flaked off to a depth of about one inch on the fire exposed surface. The time allowed for setting before performing fire tests deserves some attention according to Miller [7]. Indeed, he stated that "[A] maximum limit should be fixed dependent on the interval between construction of a building and its occupancy in ordinary cases." One interpretation of this must be that a concrete structure shall have the required fire resistance from day one when it is taken into service. This is not the approach used later when a test specimen is "required"1 to be in moisture balance with the surroundings before testing.

1911 Early categorization of the fire spalling of concrete. During several fire test series performed by Gary [8-10] in concrete buildings, different fire spalling phenomena were observed. MayerOttens [11] summarized the phenomena that Gary indentified during these test in the following four types of spalling ${ }^{2}$ :

- Crater-shaped "aggregate spalling" - at single aggregate grains - but not at concrete with basalt aggregates. The spalling was attributed to the mineralogical character of the aggregates, especially to weathered feldspars.

- Shell-shaped explosive Spalling at the surfaces of the structural elements - "Surface-spalling" at levels of the order of $100 \mathrm{~cm}^{2}$ up to several square meters, especially at compression loaded walls and columns, whereby the reinforcement was partially exposed. The spalling was explained by water vapor stresses in relatively wet concrete.

- Explosive spalling at the corners of joists, columns and steps - "corner-spalling" - whereby the corner reinforcement was partially exposed. Simultaneously tested sandstone steps also exhibited corner spalling. This spalling was also explained by water vapor stresses and temperature stresses due to bilateral rapid heating.

- Explosive spalling at the walls, whereby up to $1 \mathrm{~m}^{2}$ big wall sections were fully blasted and the integrity was lost, but the bearing capacity was preserved. Wall pieces were thrown away more than $12 \mathrm{~m}$ from the experimental house.

1916 Fire spalling as a trigger for building collapse. In the Far Rockaway fire in the U.S., five of the eight levels of the concrete building were exposed to fire. The $4^{\text {th }}$ floor collapsed during the fire and extensive spalling was found in the building despite the fact that the building built in 1909 was supposed to be a first class fire proof building and the fire exposure was not particularly severe. The reason for the severe spalling behaviour was, according to Woolson [12], the use of quartz gravel from the New York

\footnotetext{
1 This requirement is defined differently in different standardized fire testing standards but the fundamental goal is moisture balance with some standardized climate although real balance it is in many cases impossible to achieve.

2 Translation from German to English by Klaus Pistol, BAM, Germany.
} 
vicinity. A special committee was appointed by the American Concrete Institute to investigate the fire further and some noteworthy findings by the committee include [13]:

- In the case of no sprinklers when a very rapid rising fire or a slow fire with long duration is suspected, special care must be taken regarding the protection of concrete.

- Round columns are preferred compared to square columns.

- If the reinforcement is placed near the surface, serious damage will likely occur and the concrete will be stripped off by the rapid expansion of the reinforcement.

- When using gravel concrete, protective coatings of concrete or other materials can be used to enhance the fire resistance during rapid fires of considerable intensity or slow fires with long duration.

- The thermal expansion of the aggregate is a very important factor influencing the fire resistance during rapidly developing fires. Quartz undergoes a critical transformation at $575{ }^{\circ} \mathrm{C}$, which is the main cause of the intense spalling during the Far Rockaway fire.

1920 Additional reinforcement close to the surface of concrete suggested to compensate for the expansion of thermally unstable aggregate. Hull [14] had the same opinion as many others that the expansion of quartz in the aggregate was the main reason for fire spalling. To limit the spalling behaviour Hull recommended adding a thin extra reinforcement layer close to the surface. More recent research has, however, indicated that the addition of an extra reinforcement layer (which is also an option in the Eurocode 1992-1-2) does not work for high strength concrete [15].

1931 Discussion of the significance of crack growth in concrete for the occurrence of spalling. Based on a microscopy study of concrete from a fire in a storage building in Sweden, Sundius [16] drew the conclusions that physical changes such as crack growth in the cement paste were induced by the expulsion of water. He also found large cracks parallel to the heated surface which he concluded could lead to flaking.

1935 New description of the main factors leading to fire spalling. In his $\mathrm{PhD}$ thesis produced at the University of Braunschweig, Hasenjäger [17] summarised the factors leading to fire spalling as being:

- Rapid heating of concrete

- Exceeding the tensile strength by unilateral strain

- Rapid structure and volume change in the aggregate

- Pressure from liberation of water vapour and gases from the aggregate and the cement paste.

Clearly Hasenjäger mainly identified two types of stresses leading to the spalling phenomena: thermal stresses and pressure from moisture. The relative importance of these two factors has since been the subject of intense discussion by the scientific community.

1952 Initial concerns about the implications of mechanical vibration of modern concrete on its fire spalling performance. Concerns were voiced by Sönnerberg [18] that concrete moulded using modern methods (mechanical vibration) have been seen to spall leading to a reduced fire resistance when exposed to fire. The modern concrete was found to be denser compared to traditionally "tampered" concrete. When concrete is exposed to heat during a fire, the water which is always present in free or bound form in concrete will evaporate and strive towards the surface through cavities. If the concrete is dense, this moisture transport is somewhat hindered so high gas pressures can result leading to explosions of the surface layers of the structural member (i.e. spalling). This can happen even due to rather weak fire exposure. According to Sönnerberg [18] more research and testing were needed to solve this problem.

1961 Emergence of the Moisture Clog Theory. A classical approach to the role of moisture was formulated by Shorter \& Harmathy [19] in their Moisture Clog Theory. When a concrete specimen is heated, water desorbs in a thin layer close to the surface. The pressure gradient then drives moisture not only out of the specimen but also towards the inner (colder) parts of the concrete specimen. When the 


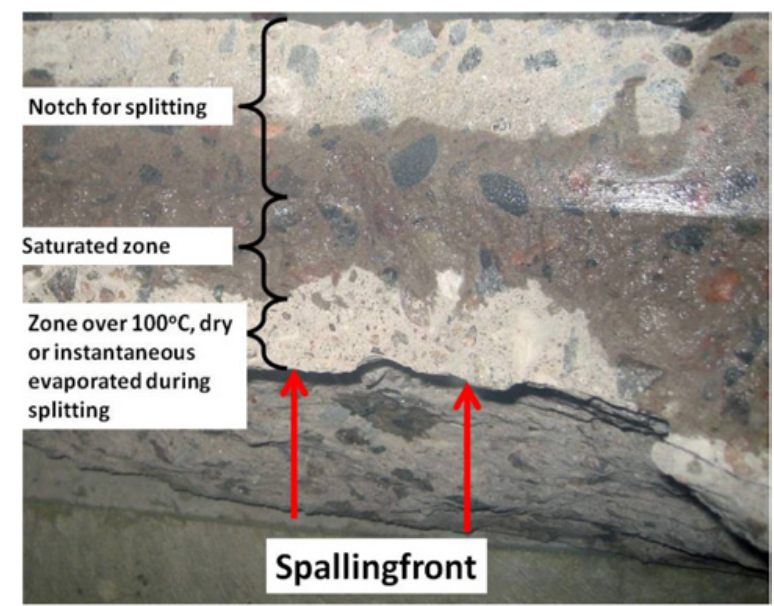

Figure 1. The moisture clog as observed by splitting a spalling $600 \times 500 \times 200 \mathrm{~mm}$ slab directly removed from the furnace [21]. Photo: Robert Jansson.

steam meets a neighbouring colder layer it will condense. This process will continue, moving further into the cross-section, until a fully saturated region of "considerable thickness" [20], is created. This region is the so called "moisture clog". When the moisture clog is created, further movement of steam inwards towards the colder regions is restricted. The description is obviously a simplification because in a real situation the temperature and pressure fields will not be linear as in illustrations by Harmathy [20], but the main point is that the highest pressure will be developed at the boundary of the moisture clog and when (or if) this pressure exceeds the tensile strength of the concrete, a piece will spall away. According to Shorter \& Harmathy [19] it is not necessary to assume that the explosive release of energy, or spalling, comes from expanding water alone as the dry layer closer to the surface is already highly stressed by thermal expansion. The presence of moisture leads to two effects that can contribute to the spalling behaviour: it leads to a sharp temperature gradient and a vapour pressure force. Experiments by Shorter and Harmathy show that when a concrete sample made from a concrete known to spall is pre-dried to produce a dry layer of thickness 2-2.5 in. (approx. 50-65 mm) it does not spall. They then concluded that it is reasonable to suppose that for every concrete a critical moisture content or moisture content distribution could be found below which no spalling will occur. Unfortunately, however, they did not support this with further experimentation. A visual observation of a moisture clog is shown in Figure 1.

1965 A refined theory by Saito on the cause of fire spalling. At an F.I.P. meeting in Braunschweig on the subject "Fire resistance of prestressed concrete", the local host of the meeting, professor Kordina, summarized the discussion held on the cause of spalling as [4]:

"We are not in a position to name a specific cause of spalling but a combination of the following factors could lead to dangerous spalling:

a) Residual stress due to nonuniform heating in the cross section or between flanges and stem of a beam

b) Excessive longitudinal restrain

c) High moisture content

d) Closely spaced reinforcement

e) Mineralogical character of aggregates".

Other noteworthy additions to the discussion during the meeting were:

"Spalling which usually occurred within 15-30 minutes after fire attack and was most frequent when there was a quick rise in temperature could lead to substantial loss of material." 


\begin{abstract}
"Application of a house steam did not appear to be conductive to dangerous spalling".
"Mr. Gustaferro reported that mesh wire was not always effective against spalling and experience in America indicated that stirrups, spaced not too far apart, were preferable."

"Mr. Gustaferro pointed out that spalling had not occurred with normal concrete specimens when using either lime, dolomite, or quartz aggregates."
\end{abstract}

In the proceedings from the meeting [4] Saito presents his theory of the cause of explosive spalling. According to his theory explosive spalling is initiated by thermal stresses leading to compressive failure, especially in pre-stressed concrete members where the tensile cracking in the central part is restricted. When no pre-stress or longitudinal restraint is present, the compressive stress close to the surface is reduced by internal tensile cracking. The same is true when pre-stressed concrete is subjected to bending moment where the compressive stresses on the heated side become lower leading to a delay in the spalling behaviour. Saito noted that this difference between loaded and unloaded pre-stressed members can be seen in the results from fire tests performed by England. The influence of the amount of free water in ordinary concrete that has been seen in fire tests is explained by changes in the thermal profile. With a large amount of water present in the porous system the temperature gradient will be larger and higher stresses and strains will be developed according to this theory.

1966 A fire spalling theory based on stresses from fast vapour flow in porous system presented. The importance of frictional forces during vapour flow has been elucidated by Waubke [22], MeyerOttens [11] and Waubke \& Schneider [23]. As the cross-section is heated, moisture will flow out on the fire exposed side. This flow will give rise to wall friction which will result in tensile stresses in the capillary system. The fundamental idea of the work by Waubke \& Schneider [23] was to conduct a reverse calculation, assuming that all moisture must be expelled during heating. A theoretical calculation, including a comparison of the influence of different parameters on this evacuation, then concluded that frictional stresses originating from vapour flow during fire exposure, made spalling probable.

1972 Extensive study shows the effect of load and heating from more the one side on the spalling sensitivity. In an extensive study by Meyer-Ottens [11], the influence of aggregate type, concrete quality, reinforcement, moisture content shape of the member and compressive stresses on spalling was investigated. One of the most important conclusions from the study was the clear effect of compressive stress on the amount of spalling on elements heated from two sides. The results were based on tests performed on concrete with the compressive strength of 22.5, 45 and $60 \mathrm{MPa}$. The results from Meyer-Ottens were included in a previous version on the Eurocode 1992-1-2.

1971 A further refinement of the thermal stress theory presented by Saito. A serious shortcoming in the theory by Saito, described above (1965), is according to Dougill [24] that concrete is not a linear elastic material so failure does not necessarily occur when the compressive stresses at a point reach its maximum value. He also pointed out that Saito's theory could not explain the explosive nature of the failure. According to Dougill an important factor in the explosive nature is a type of spring effect caused by the internal tension region. He compared the phenomenon with a compressive test made with a testing machine that is not stiff enough, i.e. a violent failure caused by accumulated energy will occur.

1974 Similarities between flame cleaning of concrete and fire spalling. In an experimental study by Johansson [25] on flame cleaning of concrete some parallels to fire spalling can be found. Flame cleaning is a thermal shock method for taking away the outer surface layer of concrete with an oxygeneacetylene flame with a temperature of approximately $3100^{\circ} \mathrm{C}$. During the process the flame is moved at an optimal speed over the surface layer so either the surface spalls away or melts and becomes fragile. Thereafter the melted parts are brushed away. During the experiments the low strength concrete with aggregate made of blast furnace slag was harder to clean than the mixes with other more commonly used aggregates. A small influence of strength on flaking off could also be seen as high strength concrete was slightly easier to clean than low strength concrete. Moreover a clear effect of moisture content could be seen as slabs that were watered one hour before the test flaked off much more evenly than dried concrete where large areas could not be induced to flake off. 


\section{MATEC Web of Conferences}

Table 1. Spalling results from Hertz [29] on unloaded cylinders made of ultra high strength concrete exposed to the heating rate $1^{\circ} \mathrm{C} / \mathrm{min}$. Three similar cylinders per temperature were tested.

\begin{tabular}{|c|l|l|l|}
\hline Max temperature $\left[{ }^{\circ} \mathrm{C}\right]$ & Cylinder A & Cylinder B & Cylinder C \\
\hline 150 & No explosion & No explosion & No explosion \\
\hline 350 & Exploded & No explosion & No explosion \\
\hline 450 & Exploded & Exploded & No explosion \\
\hline 650 & Exploded & Exploded & No explosion \\
\hline
\end{tabular}

1976 A program for calculation of temperature moisture and pressure distributions in concrete exposed to fire with the goal to investigate fire spalling. Bennet, Claesson \& Thelandersson [26] made a computer program for calculating temperature, moisture and pressure distributions in fire exposed concrete. The results from calculations based on a chosen set of properties for concrete show maximum pressures around $1 \mathrm{MPa}$ and stagnations of temperature rise close to $200^{\circ} \mathrm{C}$ when water in the pressurized pores evaporates.

1978 The impact of the addition of polypropylene fibres on the fire performance of concrete as testes at the Fire Research Station. A concrete panel of $0.9 \mathrm{~m}$ square and $50 \mathrm{~mm}$ thickness containing $1.2 \%$ by volume polypropylene fibres was fire tested at the Fire Research Station in UK. According to Hannant [27], no difference regarding fire resistance was found between similar concrete specimens with and without the fibre addition. The fibre type tested is not described in detail but it was probably a thick type of fibre compared with the fibres commonly used today to reduce fire spalling behaviour. In a comment on the shortcomings of polypropylene fibres Hannant [27] stated that after a fire an extra porosity equal to the volume of the added fibres is present where the fibres have been combusted. There is hence a risk that the long term durability is reduced after relatively small fires when the fibres melt away. This is an issue which has still not been resolved.

1979 Study of fire spalling of concrete with focus on drying. Based on an empirical research program and a literature survey, Copier [28] drew conclusions on the importance of different factors on the fire spalling of concrete. The principal cause of spalling was stated to be the moisture content but this was combined with the following important influences:

- heating from one or two sides

- reinforcement or no reinforcement

- compressive stress or no compressive stress

- thickness of the member.

Less important factors were found to be:

- the quality of the reinforcement (provided that the bars are not too closely spaced)

- the magnitude of compressive stress applied

- the quality of concrete (if suitable for structural purpose)

- the distribution of moisture in the cross section

- for lightweight concrete: the type of lightweight aggregate used.

1982 Small cylinders of ultra high strength concrete were shown to spall at low heating rate. Hertz $[29,30]$ found that some cylinders, diameter $100 \mathrm{~mm}$ and height $200 \mathrm{~mm}$, made with the addition of silica fume and with a strength of $170 \mathrm{MPa}$, spalled explosively although the heating rate was as low as $1{ }^{\circ} \mathrm{C} / \mathrm{min}$ and no external load was applied during the heating, see Table 1. According to Hertz [30] the reason for the explosion was the dense micro-structure that hindered the steam to escape. He also added that there is reason to believe that the chemically bound water of the hydrated calcium silicates is enough to cause an explosion.

1983 Water transport around polypropylene fibres suggested as the mechanism to relieve fire spalling in refractory materials. In a patent Long \& Moeller [31] describe the use of polypropylene 
IWCS 2013

Table 2. Main spalling theories with sub groups according to Malhotra [32].

\begin{tabular}{|l|l|}
\hline 1) Moisture & 1a) Vapour pressure \\
\hline & 1b) Moisture clogging \\
\hline & 1c) Vapour pressure enhanced by frictional resistance \\
\hline 2) Stress & 2a) Initial compression \\
\hline & 2b) Initial compression + thermal stress \\
\hline & 2c) Initial compression + thermal stress + stress caused by frictional resistance \\
\hline 3) Cracking & 3a) Aggregate expansion \\
\hline & 3b) Internal cracks \\
\hline & 3c) Reinforcement expansion \\
\hline
\end{tabular}

Table 3. Highlighted theories by different researchers, compilation by Malhotra [32].

\begin{tabular}{|l|l|l|}
\hline Researcher & Main factors & Secondary factors \\
\hline 1) Saito [33] & 2a, 2b, 2c & 1a \\
\hline 2) Harmathy [20] & 1b & - \\
\hline 3) Meyer-Ottens [11] & 1c, 2b & 2c, 3c \\
\hline 4) Dougill and Sertmehmetoglu [34] & 1b, 3b & 2a \\
\hline 5) Akhtaruzzaman and Sullivan [35] & 1a & Dense surface layer \\
\hline 6) Gustaferro [4] & 1a & 3a \\
\hline 7) Copier [28] & 2a, 1a & - \\
\hline
\end{tabular}

fibres with the diameter of $15 \mu \mathrm{m}$ to solve the problem of explosive spalling of refractory materials. In an electron microscopy study small annular passageways or channels with the thickness of approximately $1 \mu \mathrm{m}$ around each polypropylene fibre were found in the refractory material. According to Long \& Moeller water transport in these channels was caused primarily by capillary forces but also pressure differences.

1984 Survey on fire spalling theories. To illustrate the whole palette of spalling theories, a survey performed by Malhotra [32] provides an overview of which theories various researchers consider to be the primary and secondary causes of spalling during the 60's and 70's. The different causes are summarised in Table 2.

In Table 3, the different theories are graded by different researchers.

1992 Study on the influence of steel fibres on the fire spalling of concrete. During a continuation of the work on high strength silica concrete performed in the early eighties, Hertz [36] conducted a study of the influence of adding steel fibres to the concrete with the compressive strength $170 \mathrm{MPa}$ used in the previous tests. The results showed that the explosions were not hindered by adding steel fibres but delayed to higher temperatures. The cylinders with diameter $100 \mathrm{~mm}$ and height $200 \mathrm{~mm}$ were pulverized by the explosion. This should be compared with the behaviour during tests on cylinders without steel fibres that were exploding into larger pieces. Tests on smaller cylinders with the diameters 100 and $52 \mathrm{~mm}$ were also included in the study. Cylinders with these smaller diameters did not spall at all. This shows a clear size effect on the occurrence of spalling.

1994 Significant fire incident identifies progressive fire spalling in real fires. On the morning of June 11, 1994, a fire started in the tunnel boring machine (TBM) in the Great Belt Tunnel. As described by Tait \& Höj [37] and Höj \& Tait [38], the primary fuel in the fire was the hydraulic oil from the TBM. The fire developed rapidly and could not be extinguished so it had to burn itself out. Based on observation of the smoke from the fire it was estimated that the fire continued for between 4 to 8 hours. The concrete mix included micro silica, fly ash, and granite aggregate and had an equivalent water/cement ratio of 0.32 leading to a 28 -day strength of $76 \mathrm{MPa}$. According to the state-of-the-art knowledge at that time, spalling should have been confined to the cover of the concrete, $40 \mathrm{~mm}$, and 


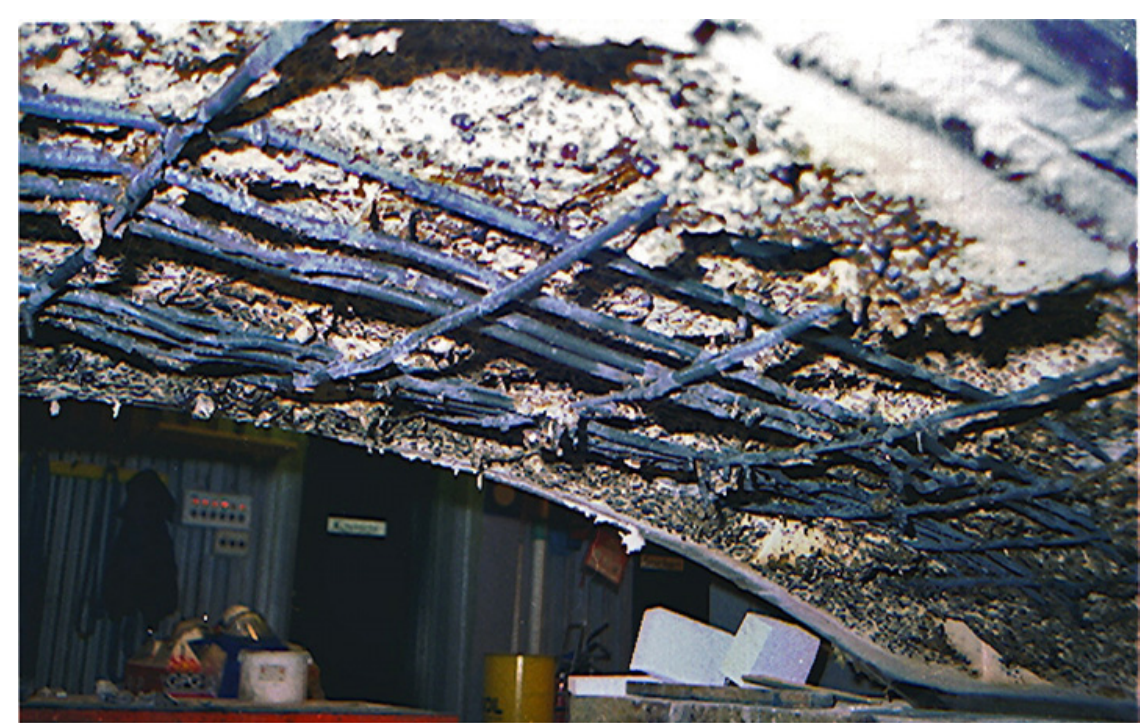

Figure 2. Tunnel element from the Great Bealt tunnel fire tested at SP Technical Research Institute of Sweden. Photo included in the official report from the Danish Transport Authority [39].

take place during the first 20 minutes of fire exposure. This estimated limitation in spalling severity was not reflected in the real fire incident. In the segment that was most affected by the fire only a third of the $400 \mathrm{~mm}$ thick cross section remained, the rest had spalled away contrary to the predictions of that time.

As an emergency measure the spalled areas were covered by reinforced shotcrete to the original thickness but due to increasing inflow of groundwater through the badly cracked segments evacuation of all personnel were made and no entry was allowed until a full investigation had been undertaken. Bulkheads including flood doors were installed to reduce the risk if the lining was to fail and flooding occur. To refurbish the tunnel as rapidly as possible, available tunnel segments of the type RB2 SG1 from the Channel Tunnel were used. However, as the diameter of the standard elements from the Channel Tunnel was larger modifications were made to make them fit. The new elements were put onto top of the spalled elements and resulting cavities were filled with grout.

To further investigate the unexpected amount of fire spalling and to broaden our understanding of the behaviour of the concrete elements, fire tests were performed on two tunnel segments from the production. The fire tests were performed at SP Technical Research Institute of Sweden and described more in detail in an official report from the Danish Transport Authorities [39]. When the fire test was performed the moisture content in the concrete was approximately $4 \%$ which was assumed to be the same as in the segments in the tunnel during the real fire event. The outcome of the experiments was that the spalling degree was less during the fire test compared to the real fire despite the fact that the fire exposure used in the furnace testing, the RABT fire curve, was estimated to be more severe than the real fire. Although the fire spalling during the experiment was less than during the real fire, $140 \mathrm{~mm}$ compared with $227 \mathrm{~mm}$, the original assessment that the spalling would only take place in the cover, $40 \mathrm{~mm}$, was confirmed to be incorrect. The fire exposed surface of the concrete element after fire testing is shown in Figure 2. The actual fire event and the ensuing fire test show a typical example of progressive spalling.

1997 The hydraulic spalling theory based on fracture of fully saturated pores. According to Khoylou [40] the probable cause of fire spalling of concrete is the occurrence of fully saturated pores. If more than $32 \%$ of a closed pore is initially filled with water, the water will expand during heating and force the trapped air into solution resulting in a fully saturated pore at elevated temperatures. 
The same phenomenon that Khoylou describes is used as the activation mechanism for sprinklers with bulb activation, where a glass container is filled with water and a bubble. When the temperature rises sufficiently the water expands and the air is forced into solution in the water until the whole bulb is filled and breaks due to the build up of hydraulic pressure.

2000 The BLEVE (Boiling Liquid Expanding Vapour Explosion) theory for fire spalling. The BLEVE theory can, according to Ichikawa [41], be a component in the spalling process of high strength concrete. When the pressure is released from a pore including high temperature liquid water the conversion into steam is very rapid as all energy accumulated during heating up over $100^{\circ} \mathrm{C}$ will be released in an instantaneous boiling process that is classified as an explosion. Petrov-Denisov et al. [42] also present a theory including the rapid expansion of super heated water. According to their theory the walls between closed pores with super heated water and open pores with lower pressure can be destroyed by the pressure difference and as Hertz [43] points out this can lead to a progressive breakdown of the microstructure.

2008 Fire spalling theory based on reduction of strength in locally saturated concrete and absence of relaxing drying creep presented. In an attempt to explain experimental observations, a theory for fire spalling based on the reduction of strength in locally saturated areas in the cross-section combine with the absence of drying creep was postulated by Jansson [44].

\section{CONCLUSIONS}

Clearly there is no universally accepted theory for the fire spalling of concrete. Most probably there are different causes of the fire spalling phenomenon in different situations which will require case specific theoretical explanations. Our knowledge base for the development of physical models is continually improving but the confirmation of different theories is confounded by experimental difficulties associated with measuring key parameters such as pore pressure, stress, strain etc. in the zone of interest during fire exposure.

\section{References}

[1] Barret, On the French and other methods of constructing iron floors, Civil Engineering and Architect's Journal, Vol XVII, pp 94,1854.

[2] Ingle J., Recent improvements in the application of concrete to fire-proof constructions, London Civil Engineering and Architects' Journal, pp 378-381, 1866.

[3] Swedish Tariff Association, Concrete and Fire (in Swedish), A book published by the Swedish Tariff Association, 112 pages, 1959.

[4] Kordina K., Fire resistance of prestressed concrete, Proceedings of a symposium on the fire resistance of prestressed concrete, held under the auspices of the F.I.P. Commission on Fire resistance of prestressed concrete at Braunschweig, Germany, June 1965.

[5] Woolson I., Investigation of the Effect of Heat Upon the Crushing Strength and Elastic Properties of Concrete, Proceedings of the American Society for Testing Materials, 1905.

[6] Lange D., Sjöström J., Jansson R and Boström L., Deflection of concrete floor slab during a fire test: Testing and modelling, 15th International Conference on Experimental Mechanics ICEM15, Faculty of Engineering, University of Porto, Portugal, 22-27 July 2012.

[7] Miller R. P. Contribution to the discussion at the end of the report "Investigation of the Effect of Heat Upon the Crushing Strength and Elastic Properties of Concrete" by Ira Woolson, Proceedings of the American Society for Testing Materials, 1905.

[8] Gary, M., Brandproben an Eisenbetongbasuten (in German), Deutcher Ausschlutss für Eisenbetong, Heft 11, Berlin, Germany, 1911.

[9] Gary, M., Brandproben an Eisenbetongbasuten (in German), Deutcher Ausschlutss für Eisenbetong, Heft 33, Berlin, Germany, 1916. 


\section{MATEC Web of Conferences}

[10] Gary, M., Brandproben an Eisenbetongbasuten (in German), Deutcher Ausschlutss für Eisenbetong, Heft 41, Berlin, Germany, 1918.

[11] Meyer-Ottens C., Zur Frage der Abplatzungen an Betonbauteilen aus Normalbeton bei Brandbeanspruchung, PhD-thesis, Braunshweig, Germany, 1972.

[12] Woolson I., Fire in a reinforced concrete warehouse at Far Rockaway, New York, U.S.A, RED BOOKS of the British Fire Prevention Committee, No. 21, 1918.

[13] Humphrey R., Report of committee on far rockaway fire, Chairman Richard Humphrey, Proceedings of the Seventeenth Annual Convention of the American Concrete Institute, Chicago, February 14-16, 1921.

[14] Hull W. , Fire tests of concrete columns, Proceedings of the Sixteenth Annual Convention, American Concrete Institute, Chicago, 1920.

[15] Diederichs U., Jumppanen U-M. \& Schneider U., High Temperature Properties and Spalling Behaviour of High Strength Concrete, Proceedings of the Fourth Weimar Workshop on HighStrength Concrete: Material Properties and Design Held at Hochschule fur Architcktur und Bauwesen (HAB), Weimar, Germany, Oct. 1995.

[16] Sundius N., Investigation of fire exposed concrete by microscopy (in Swedish) BETONG, Number 2, 1931.

[17] Hasenjäger, Über das Verhalten des Betons und Eisenbetons im Feuer und die Ausbildung von Dehnungsfugen im Eisenbetonbau, Dissertation, Techniche Hochschole Braunschweig 1935, as cited by: Meyer-Ottens C., Zur Frage der Abplatzungen an Betonbauteilen aus Normalbeton bei Brandbeanspruchung, PhD-thesis, Braunshweig, Germany, 1972.

[18] Sönnerberg S., The fight against fire (in Swedish), A book published by Berneces Förlag AB, Malmö, Sweden, 1952.

[19] Shorter G. W. \& Harmathy T. Z. Discussion on the article "The fire resistance of concrete beams" by Ashton and Bate, Proceedings, Institute of Civil Engineers, Vol. 20, 1961, p. 313.

[20] Harmathy, T. Z., Effect of moisture on the fire endurance of building materials, Moisture in Materials in Relation to Fire Tests, ASTM Special Technical Publication No. 385, pp 74-95, 1965.

[21] Jansson R., Fire spalling of concrete, $\mathrm{PhD}$ Thesis, Royal Institute of Technology, Stockholm, 2013.

[22] Waubke N. V. "Transportphänomene in Betonporen", Dissertation, Technishe Universität Braunschweig, 1966.

[23] Waubke N. V. and Schneider U., Tensile stress in concrete due to fast vapour flow, Proceedings of the international RILEM symposium "Pore Structure and Properties of Materials", Prauge, September, 1973.

[24] Dougill J. W., Modes of failure of concrete panels exposed to high temperatures, Magazine of Concrete Research, Vol 24, No 79, June, 1972.

[25] Johansson L., Flame cleaning of concrete (in Swedish) Report 7424, Swedish Cement and Concrete Research Institute, 1974.

[26] Bennet J., Claesson J. and Thelandersson S., Calculations of temperature, moisture, and pressure distributions in concrete exposed to fire, Report from the Department of Mathematical Physics, Division of structural Mechanics, University of Lund, November 1976.

[27] Hannant D. J., Fiber Cements and Fiber Concretes, Book published by John Wiley \& Sons, Ltd, 1978.

[28] Copier W. J., The spalling of normal weight and lightweight concrete on exposure to fire, Heron, Vol 24, No 2, The Nederlands, 1979.

[29] Hertz K., Explosion og reststyrke af varmepåvirket silikabeton (in Danish), Report 162, Danmarks tekniske Höjskole, Ljungby, 1982.

[30] Hertz K., Explosion of Silica-fume Concrete, Fire Safety Journal, No 8, 1984/85. 
[31] Long W. G. \& Moeller H. H., Rapid Fire Refractories, United State Patent 4,419,451, December 6, 1983.

[32] Malhotra H. L., Spalling of concrete in fires, Technical note 118, CIRA, 1984.

[33] Sato H., Explosive spalling of prestressed concrete in fire, Japanese Building Research Institute, Occasional Report 22, Ministry of Construction, Tokyo, Japan, 1965.

[34] Sertmehmetoglu Y., On a mechanism of fire soalling of concrete under fire conditions, $\mathrm{PhD}$ Thesis, Kings College, London, Great Britain, 1977.

[35] Akhtaruzzaman A. A. and Sullivan P. J. E., Explosive spalling of concrete exposed to high temperature, Concrete Structures Research Report, Imperial College, Great Britain, 1970.

[36] Hertz K., Danish Investigations on Silica Fume Concretes at Elevated Temperatures, ACI Materials Journal, July-August, 1992.

[37] Tait C. \& Höj N. P., Storebaelt Eastern Railway Tunnel: Dania Tunnel Boring Machine FireAnalysis and Recovery, Proceedings of the Institution of Civil Engineers, Supplement to Civil Engineering, Vol 114, Special issue 1, 1996.

[38] Höj N. P. \& Tait C., Great Belt Tunnel Repairs and Refurbishment Following a Fire, 2nd International Conference on Tunnel Management, Operation and Maintenance, Seminar on Tunnel Fires, Hong Kong, China, February 16-18, 1998.

[39] Trafikministeriet (1995), Sikerhet ved Transport gennom Storebealtstunnelen, Official report from Trafikministeriet (in Danish), Denmark, November, 1995.

[40] Khoylou N., Modelling of moisture migration and spalling behaviour in non-uniformly heated concrete, PhD thesis, University of London, March, 1997.

[41] Ichikawa Y., Predictions of pressures, heat and moisture transfer leading to spalling of concrete in fire, PhD Thesis, Imperial Collage, London, Great Britain, 2000.

[42] Petrov-Denisov V.G., Maslennikov L.A. and Pitckob A.M., Heat- and moisture transport during drying and first heating of heat resistant concrete (In Russian). Concrete and Reinforced Concrete 1972;2: 17-8 as cited by Herz 2003 [x].

[43] Hertz K., Limits of Spalling of Fire-Exposed Concrete, Fire Safety Journal, No 38, 2003.

[44] Jansson R., Material properties related to fire spalling of concrete, Licentiate Thesis, Report TVBM-3143, Lund University, 2008. 